\title{
Partial Purification of Phytocystatin from Moringa oleifera lam.
}

\author{
Abdullahi Abdulkadir ${ }^{1}$, Adamu Yusuf Kabiru ${ }^{1}$, Muhammad Hadiza Lami ${ }^{1}$, Bala Alkali \\ Mohammed $^{1,2} *$, Tawakaltu Abdulrasheed-Adeleke ${ }^{1}$
}

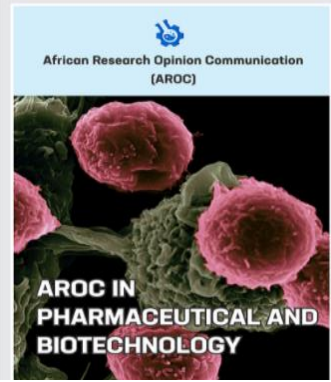

${ }^{1}$ Department of Biochemistry, Federal University of Technology, Minna, Niger state, Nigeria ${ }^{2}$ Department of Chemistry and Chemical Biology, University of New Mexico, Albuquerque, New Mexico 87131, USA

*Corresponding author Bala Alkali Mohammed

Email: b.mohammed@ futminna.edu.ng

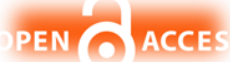

\begin{abstract}
Background: Phytocystatins are plants cysteine protease inhibitors (CPIs) that are known for their numerous uses in medicine and biotechnology. Methods: Different extraction media which include, Sodium Hydroxide, Hydrochloric acid, Sodium Chloride, Sodium phosphate buffer and distilled Water were used to evaluate flower, leave, root, latex, and stem bark of Moringa oleifera for inhibitory activity against cysteine protease (Papain enzyme). The phosphate buffer extract with higher protease inhibitory activity was concentrated by cold acetone precipitation and further subjected to partial purification using ammonium sulphate fractionation and Hydrophobic chromatography on Phenyl Sepharose column. The molecular weight of partially purified protein was estimated by sodium dodecyl sulphate (SDS) polyacrylamide gel electrophoresis. Results:_The extracts of Sodium phosphate buffer from the seeds of Moringa oleifera showed higher CPI activity of $11.23 \mathrm{units} / \mathrm{mg}$ protein. Cold acetone precipitated extract gave high yield of $94.6 \%$ protein with $60 \%$ inhibition of protease. The partially purified protein showed a fifty percent inhibitory concentration ( IC $_{50}$ ) of $1.22 \pm 0.3 \mathrm{mg} / \mathrm{ml}$ protein against the enzyme with $63 \%$ inhibition. An estimated molecular weight of $13.5 \mathrm{kDa}$ was obtained from electrophoretic analysis of partially purified protein . Conclusion: Moringa oleifera seeds could be a good source of low molecular weight protein Inhibitor of Cysteine protease and might be useful in biotechnology of traditional medicinal plants, in transgenic crops to arrest the negative pathogenic over expressions of cysteine proteases.
\end{abstract}

Keywords: Cysteine Protease Inhibition; Phytocystatin; Purification; Moringa oleifera

Received: 03 January 2021, Revised: 24 January 2022, Published: 04 January 2022

Citation: Abdulkadir, A., Kabiru, A.Y., Lami, M.H., Mohammed, B.A., Abdulrasheed-Adeleke, T. (2022). Partial Purification of Phytocystatin from Moringa oleifera lam. AROC in Pharmaceutical and Biotechnology, 2(1);09-17, https://doi.org/10.53858/arocpb02010917

\subsection{Introduction}

Phytocystatins are plant proteins cysteine protease inhibitors that constitute a powerful regulatory system for endogenous proteases which may otherwise cause excessive proteolysis and cell damages $[1,2]$. Cysteine proteases are enzymes that are expressed throughout the animal and plant kingdoms as well as in microorganisms. These enzymes have been implicated in many adaptation mechanisms for survival in the host, including modulation of the host immune system, invasion and destruction of host tissues, parasite dissemination, and acquisition of essential nutrients that assure survival and proliferation to sustain the infection [3]. This enzyme has drawn special attention as drug targets for the cure of several diseases such as osteoporosis, arthritis, cancer, and many parasitic infections [4]. The interaction between cysteine proteases and inhibitors is necessary for averting unwanted potentially destructive proteolysis [5]. These plant-derived inhibitors are gaining consideration as potential candidates which can be exploited in the [6].

Antiparasitic activity of different parts of Moringa oleifera has been reported $[7,8]$. Serine protease inhibitors with various therapeutic activities have been reported in various parts of Moringa oleifera [9], but literature on protease inhibitors from Moringa oleifera is scanty despite many reports on the presence of this molecule from plants of related families. There is a dearth of the antiparasitic activities of cysteine protease inhibitor from Moringa oleifera. Thus, the Inhibition of cysteine proteases with the inhibitor isolated from this plant become paramount and will contribute to chemotherapy of many diseases and crop production. This work aims to partially purify phytocystatin from Moringa oleifera seeds. 


\subsection{Materials and Methods}

\subsection{Chemicals}

Benzoyl-DL-argininyl-p-nitroanilide (BapNA), Papain (EC 3.4.22.2 from Carica papaya (latex) Phenyl-Sepharose CL and all other chemicals are of analytical grade.

\subsection{Plant sample collection}

The plants were collected between periods of November to January in Samaru, Zaria (Latitude $11.15^{\circ} \mathrm{N}$ and Longitude $7.65^{\circ} \mathrm{E}$ ). The plants were identified in the Department of Biological Sciences, Ahmadu Bello University, Zaria, Kaduna State with voucher number 900219

\subsection{Extraction of phytocystatin}

Fresh parts ( $25 \mathrm{~g}$ each); leaves, flowers, seeds, root and stem barks of Moringa oleifera. Each part was blended with $100 \mathrm{~mL}$ each of sodium chloride $15 \%$ $(\mathrm{w} / \mathrm{v})$, sodium hydroxide $0.2 \%(\mathrm{w} / \mathrm{v})$, hydrochloric acid $0.05 \mathrm{M}$, phosphate buffer $0.1 \mathrm{M}(\mathrm{pH} 7)$ and distilled water as described by $\mathrm{Wu}$ and Whitaker [10]. The clear supernatant obtained after homogenization and centrifugation (10,000 rpm, 15 min, $4^{\circ} \mathrm{C}$ ) represent the crude extract, and was assayed for protease inhibitor activity and protein content. The extract with highest activity was used for further studies.

\subsection{Acetone precipitation}

Four volumes of cold acetone were added with stirring to the crude extract. After 20 min stirring, the precipitate was collected by suction filtration, washed with cold acetone. The precipitate was air dried and stored at $4^{\circ} \mathrm{C}$ under desiccation. The acetone precipitate was suspended in $100 \mathrm{mM}$ phosphate buffer, $\mathrm{pH}$ 7.6. This was designated as the crude protein acetone extract [5].

\subsection{Inhibitory effect of acetone precipitate on papain activity}

Different concentrations of protein precipitate (ranging from $0.1-3.0 \mathrm{mg} / \mathrm{ml}$ ) were incubated with $1 \mathrm{mg} / \mathrm{ml}$ papain, prepared in $100 \mathrm{mM}$ phosphate buffer, pH 6.8, containing 0.3mM EDTA and $2 \mathrm{mM}$ cysteine- $\mathrm{HCl}$. The reaction was initiated with $200 \mu \mathrm{L}$ of $1.25 \mathrm{mM}$ BApNA solution for 1 hour at $37^{\circ} \mathrm{C}$. The reaction was terminated with $30 \%$ acetic acid ${ }^{10}$. Activity of inhibitor was assayed as described below.

\subsection{Protease inhibitor assay}

Protease inhibitor activity was assayed according to the method of Sritanyarat et al. [11]. Protease activity was assay using N-Benzoyl-DL-argininyl- p-nitroanilide (BapNA) as substrate. Assays were performed by adding $290 \mu \mathrm{L}$ of $50 \mathrm{mM}$ Tris $-\mathrm{HCl}(\mathrm{pH}$ 7.6) and $200 \mu \mathrm{L}$ of $1.25 \mathrm{mM}$ BApNA solution to the previously preincubated cysteine protease $(1 \mathrm{mg} / \mathrm{ml}$ papain prepared in $100 \mathrm{mM}$ phosphate buffer, $\mathrm{pH}$ 6.8, containing $0.3 \mathrm{mM}$ EDTA and $2 \mathrm{mM}$ cysteine$\mathrm{HCl}$ ) with inhibitor extract for $10 \mathrm{~min}$, at $25^{\circ} \mathrm{C}$. After 30 min at $37^{\circ} \mathrm{C}$, the reaction was stopped by adding $150 \mu \mathrm{L}$ of acetic acid $(30 \%)$. The resulting color was measured spectrophotometrically at $410 \mathrm{~nm}$. All assays were performed in triplicate. One unit of enzyme activity was defined as $1 \mu \mathrm{mol}$ of $\mathrm{p}$ nitroaniline ( $P N A$ ) released per min from the hydrolysis of BApNA under the reaction conditions. One unit of inhibitory activity corresponds to the amount of $\mu \mathrm{mol}$ of $\mathrm{p}$-nitroaniline per $\mathrm{mL}$ per min that was inhibited.

\subsection{Protein estimation from Moringa oleifera seeds extracts}

Protein content of Moringa oleifera seeds was determined according to the method of Bradford [12] using Bovine Serum Albumin (BSA) as the standard

\subsection{Purification of Crude Extracts from Moringa oleifera}

\subsubsection{Ammonium Sulphate Fractionation}

Crude protein extract was precipitated at different percentages of ammonium sulphate saturation (10$80 \%$ ). The precipitated proteins were separated by centrifugation at $10,000 \mathrm{rpm}$ at $4^{\circ} \mathrm{C}$ for $20 \mathrm{~min}$. Active protein pellets for each precipitation were dissolved in phosphate buffer and dialyzed against the buffer. The dialyzed sample was used for further purification.

\subsubsection{Hydrophobic Chromatography of Inhibitor on Phenyl-Sepharose Column.}

Hydrophobic interaction chromatography was performed on a Phenyl Sepharose [13]. The column $(1 \mathrm{~cm} \times 6.5 \mathrm{~cm})$ was equilibrated with $100 \mathrm{mM}$ sodium phosphate buffer, pH7.2 containing 1M ammonium sulphate. The active proteins from previous step were mixed with buffer $(20.0 \mathrm{ml}$, containing $1 \mathrm{M}$ ammonium sulphate, $\mathrm{pH}$ adjusted to 7.2) and was loaded onto the column at a flow rate of $0.7 \mathrm{ml} \mathrm{min}{ }^{-1}$. The bound proteins were then eluted from the column using $0.1 \mathrm{M}$ sodium phosphate buffer, $\mathrm{pH} 7.2$ containing a decreasing step gradient of ammonium sulphate $(0.5 \mathrm{M}, 0.2 \mathrm{M}$, $0.1 \mathrm{M})$. The final fraction was eluted with $0.1 \mathrm{M}$ sodium phosphate buffer, pH 7.2 containing no ammonium sulphate. Fifty fractions ( $2 \mathrm{ml}$ each) 
fractions, were collected and tested for papain inhibitory activity and protein concentration.

\subsection{Electrophoresis on SDS - PAGE}

This was carried out as described previously $[14,15]$ to ascertain the level of purity and to determine the Molecular weight of the inhibitor using $15 \%$ separating gel and $4 \%$ stacking gel. Purified samples were mixed with sample buffer in the ratio of $1: 1(\mathrm{v} / \mathrm{v})$ before heated at temperature of $100^{\circ} \mathrm{C}$ for 5 minutes. The gels were stained with $0.25 \%$ Coomassie brilliant blue in $45 \%$ ethanol $-10 \%$ acetic acid and destained with $5 \%$ ethanol- $7.5 \%$ acetic acid. The molecular weight of the inhibitor was determined by comparing to standard protein molecular marker.

\subsection{Statistical Analysis}

All Data obtained were expressed as Mean \pm standard deviation. The results were analyzed statistically using one-way analysis of variance (ANOVA) followed by Duncan multiple tests. The level of significance was set at $P<0.05$. Graph pad prism software was used to calculate $\mathrm{IC}_{50}$

\subsection{Results}

Crude extracts from different parts of Moringa oleifera obtained with various solvent media were screened for cysteine protease inhibitory activity. The recovery in terms of protein content $(\mathrm{mg} / \mathrm{ml})$, papain inhibitory activity (units/ml) and specific activity (units/mg) was determined and are shown in Figures 1-.3.

\subsection{Protein Concentrations in Different Solvents Extracts of Moringa oleifera Parts:}

All the solvents used were able to solubilize various amounts of proteins (between $0.06-3.03 \mathrm{mg} / \mathrm{ml}$ ) from parts of plants. However, the leaf and seed of $M$. oleifera showed higher protein contents compared to other parts of the plants (Figure 1 ). The protein yield of cysteine protease inhibitor extracted from Moringa oleifera seeds are summarized in Tables 1. Protein yield from cold acetone precipitation, $(\mathrm{NH} 4) 2 \mathrm{SO} 4$ precipitation, and Phenyl Sepharose chromatography is 29.32 percent.

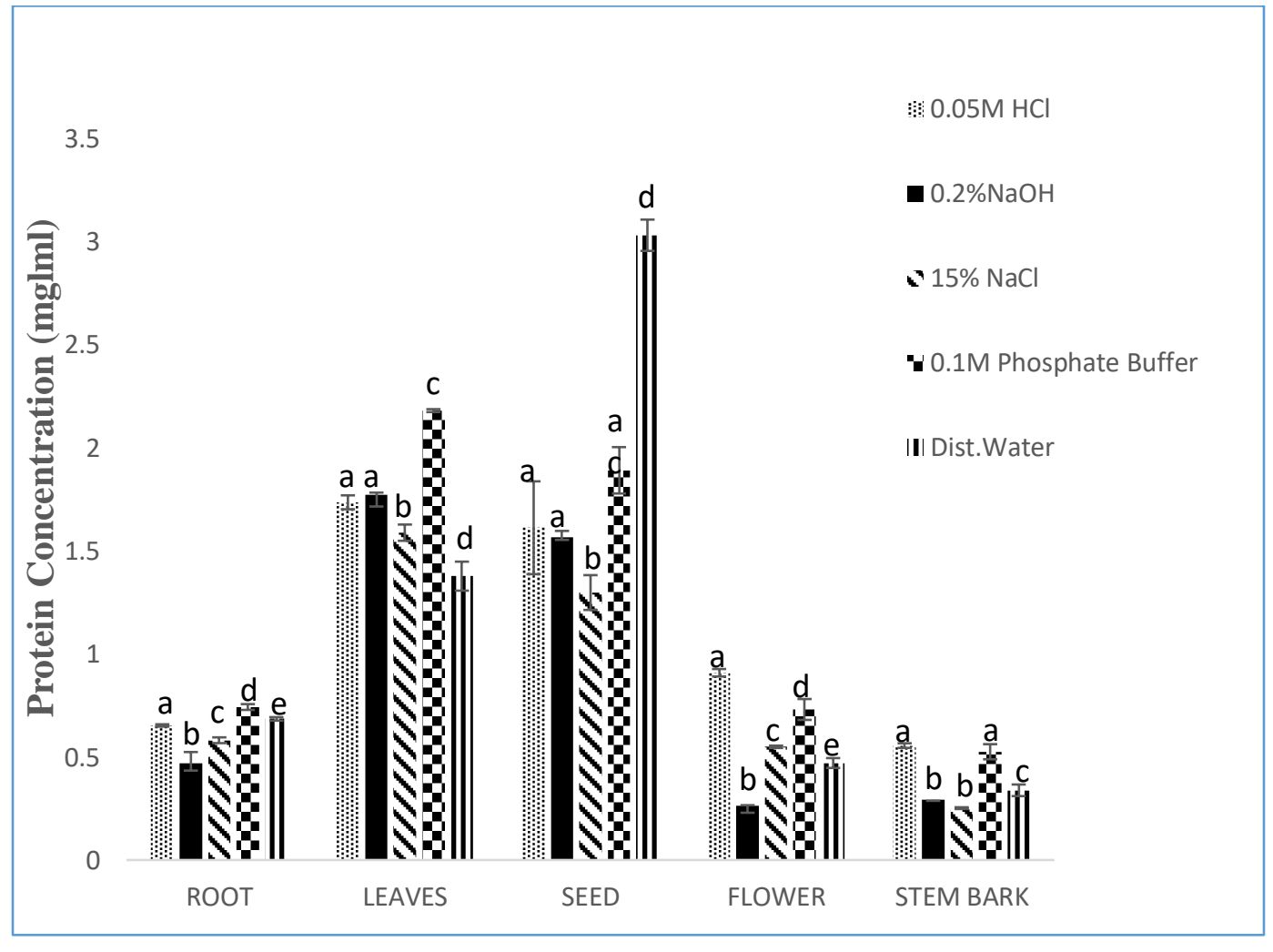

Figure 1: Protein Concentrations in Different Solvents Extracts of Moringa.oleifera Parts. Values are Mean \pm SD. $(n=3)$. Bars with different letters in the same plant part differ significantly $(p<0.05)$ 


\subsection{Protease Inhibitory Activity of Different Solvents Extracts from Moringa oleifera Parts:}

The results for inhibitory activity of the different parts of the plant extracts with papain enzyme (Figures 2) revealed that $0.1 \mathrm{M}$ phosphate buffer soluble protein extracts from seeds of $M$. oleifera possessed higher inhibitory activity of 22.43 and 21.23 units $/ \mathrm{ml}$ respectively. Sodium chloride $(15 \% \mathrm{NaCl})$ was used for the extraction of the stem bark of M. oleifera (Figure 2). Similarly, the seeds of the M. oleifera phosphate buffer extracts showed higher specific activity of 11.23 units $/ \mathrm{mg}$ protein when compared to other parts of the plant (Figure $3)$.

\subsection{Protein Yield from Moringa oleifera Seeds Extracts:}

The percentage yield recovery of acetoneprecipitated proteins from the seeds of Moringa oleifera was $12.8 \%$ (Table 1 ). The fifty percent inhibitory concentration ( $\mathrm{IC}_{50}$ ) for crude latex extract of crude seeds extract of Moringa oleifera showed $\mathrm{IC}_{50}$ of $1.22 \mathrm{mg} / \mathrm{ml}$. This was calculated from dose dependent inhibitory activity of different concentrations of acetone precipitated protein seeds of Moringa oleifera (Figure 4).

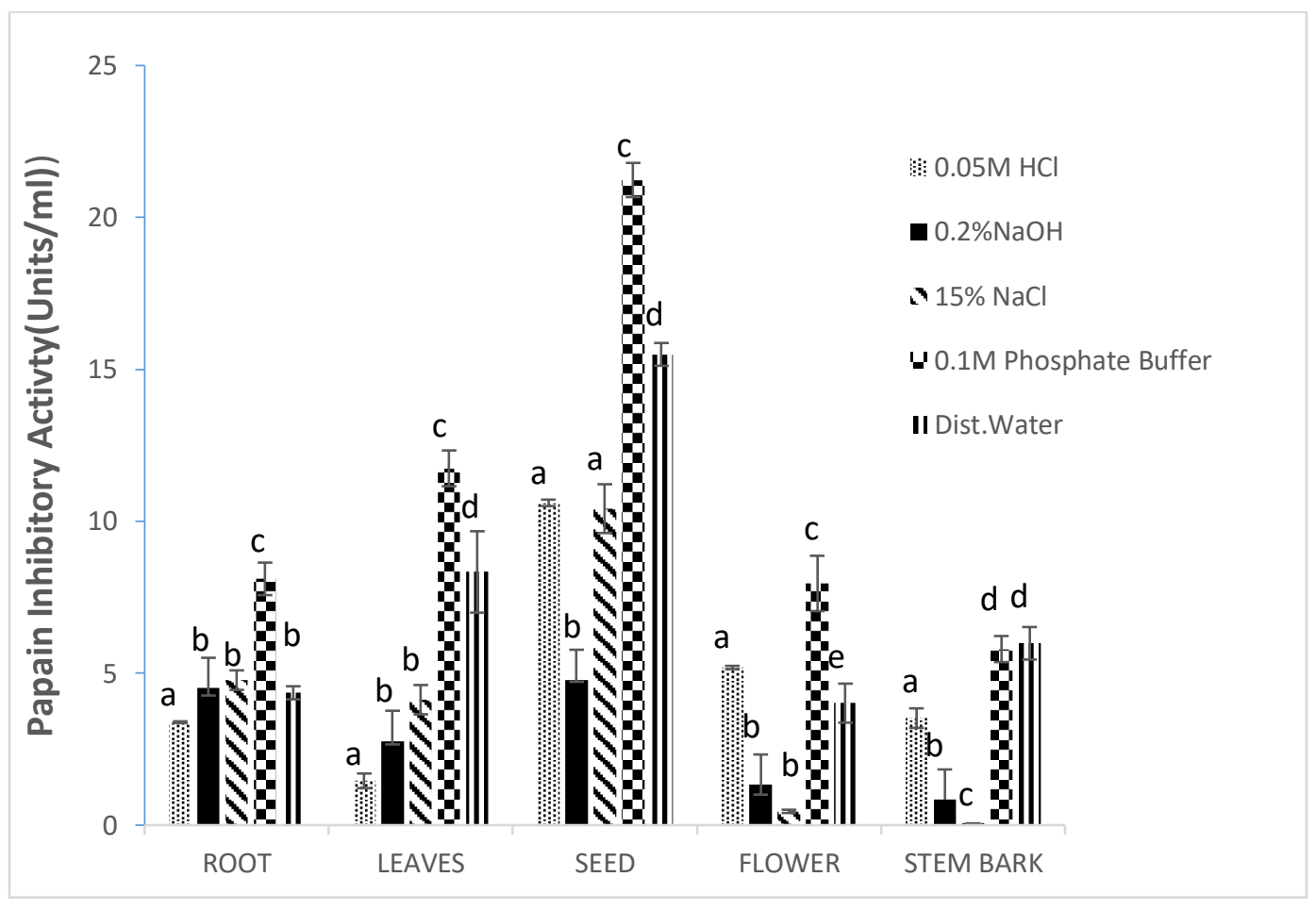

Figure 2: Protease Inhibitory Activity of Different Solvents Extracts from Moringa oleifera Parts. Values are Mean \pm SD. $(n=3)$. Bars with different letters in the same plant parts differ significantly $(p<0.05)$

Table 1: Protein Yield for the Partially Purified Extracts from Moringa oleifera Seeds

\begin{tabular}{|l|l|l|l|l|l|}
\hline & $\begin{array}{l}\text { Volume } \\
(\mathbf{m L})\end{array}$ & $\begin{array}{l}\text { Protein } \\
(\mathbf{m g} / \mathbf{m l})\end{array}$ & $\begin{array}{l}\text { Total } \\
(\mathbf{m g})\end{array}$ & protein & $\begin{array}{l}\text { Yield } \\
(\mathbf{\%})\end{array}$ \\
\hline $\mathbf{1}$ & Crude extract & 150 & 6.48 & 972 & 100 \\
\hline $\mathbf{2}$ & Acetone precipitation & 45 & 4.35 & 195.75 & 94.68 \\
\hline $\mathbf{3}$ & $\left(\mathrm{NH}_{4}\right)_{2} \mathrm{SO}_{4}$ Fraction (10-80\%) & 38 & 3.81 & 144.78 & 79.57 \\
\hline $\mathbf{4}$ & $\begin{array}{l}\text { Hydrophobic interaction Chromatography } \\
\text { (Phenyl Sepharose) }\end{array}$ & 17 & 1.9 & 32.3 & 42.34 \\
\hline
\end{tabular}




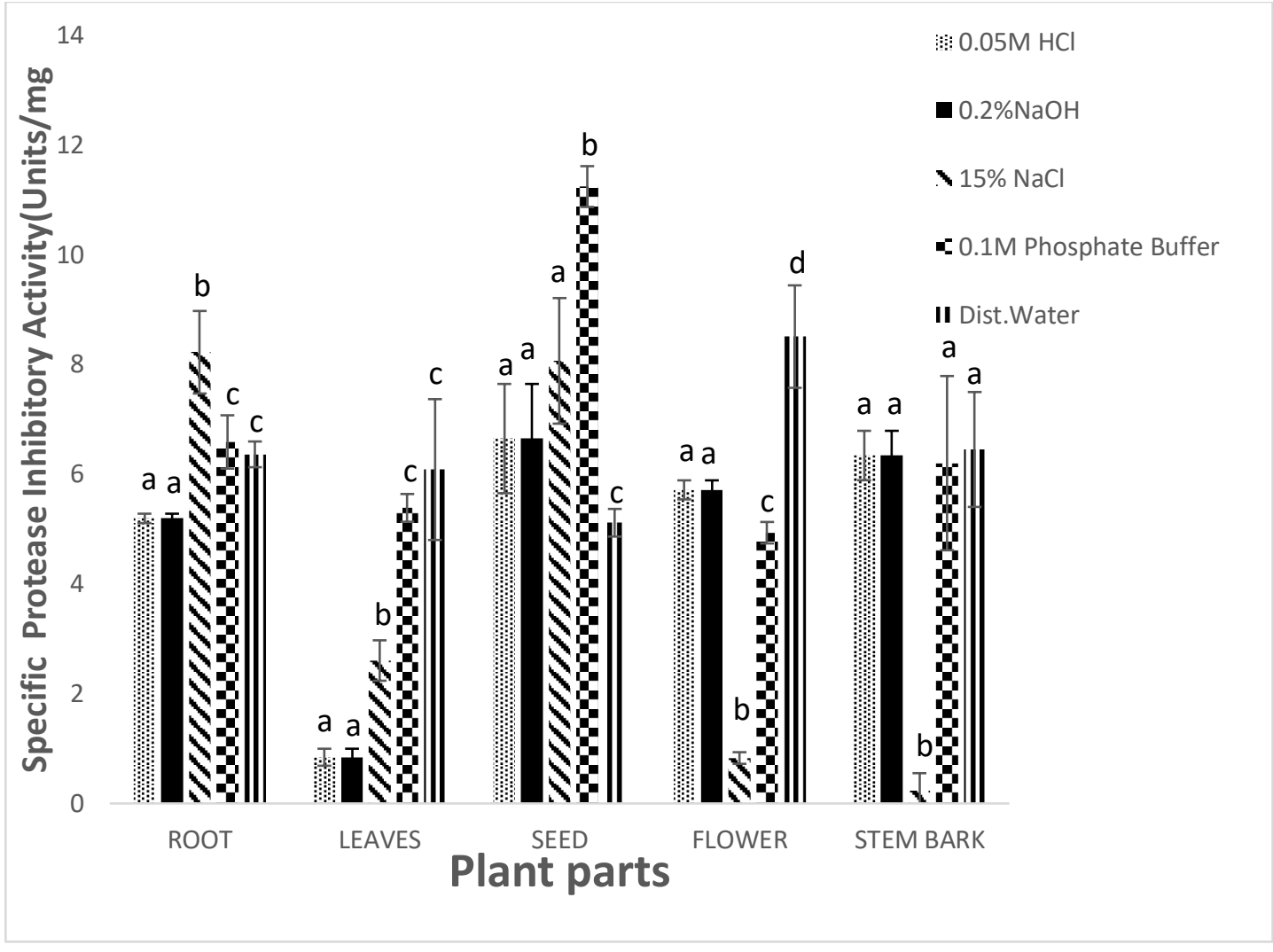

Figure 3: Specific Protease Inhibitory Activity of Different Solvent Extracts from Moringa oleifera Parts. Values are Mean \pm SD $(n=3)$. Bars with different letters in the same plant parts differ significantly $(p<0.05)$.

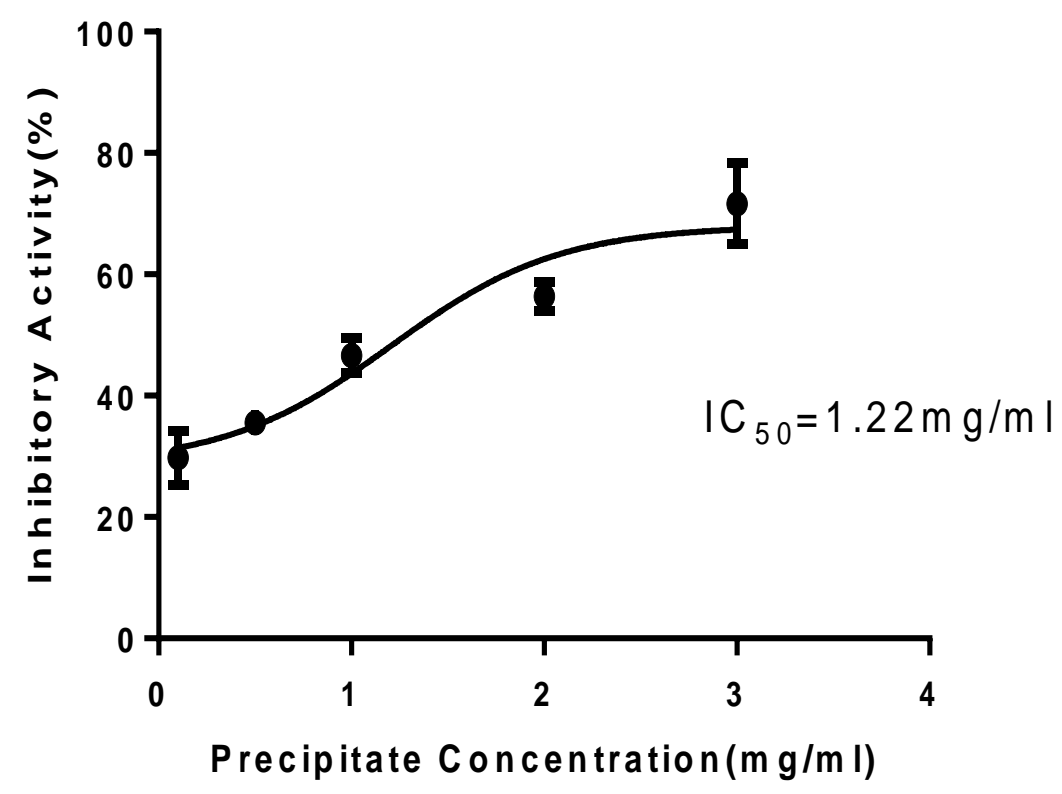

Figure 4: Protease Inhibitory Activity of the Acetone Precipitated Extracts from Moringa oleifera Seeds. Values are Mean $\pm \operatorname{SD}(n=3)$. 


\subsection{Ammonium sulphate Profile of Protease Inhibitor from Extracts of Moringa oleifera Seeds:}

Crude acetone precipitate extract proteins from Moringa oleifera seeds were subjected to ammonium Sulphate fractionation between $10-80 \%$ saturation. Precipitated proteins from Moringa oleifera seeds showed specific protease inhibition between $40-70 \%$ ammonium sulphate with maximum activity at $60 \%$ saturation (Figure 5 ).
The elution profile of fractionated proteins from Moringa oleifera seeds on phenyl Sepharose column at a flow rate of $0.7 \mathrm{ml} \mathrm{min}^{-1}$ is shown in (Figure 6). The bound active proteins fractions were eluted with sodium phosphate buffer containing $0.2 \mathrm{M}$ ammonium sulphate. The active proteins with phytocystatin activity were eluted between fractions number 7 to 17 and high activity recorded at fraction 12 (Figure 6).

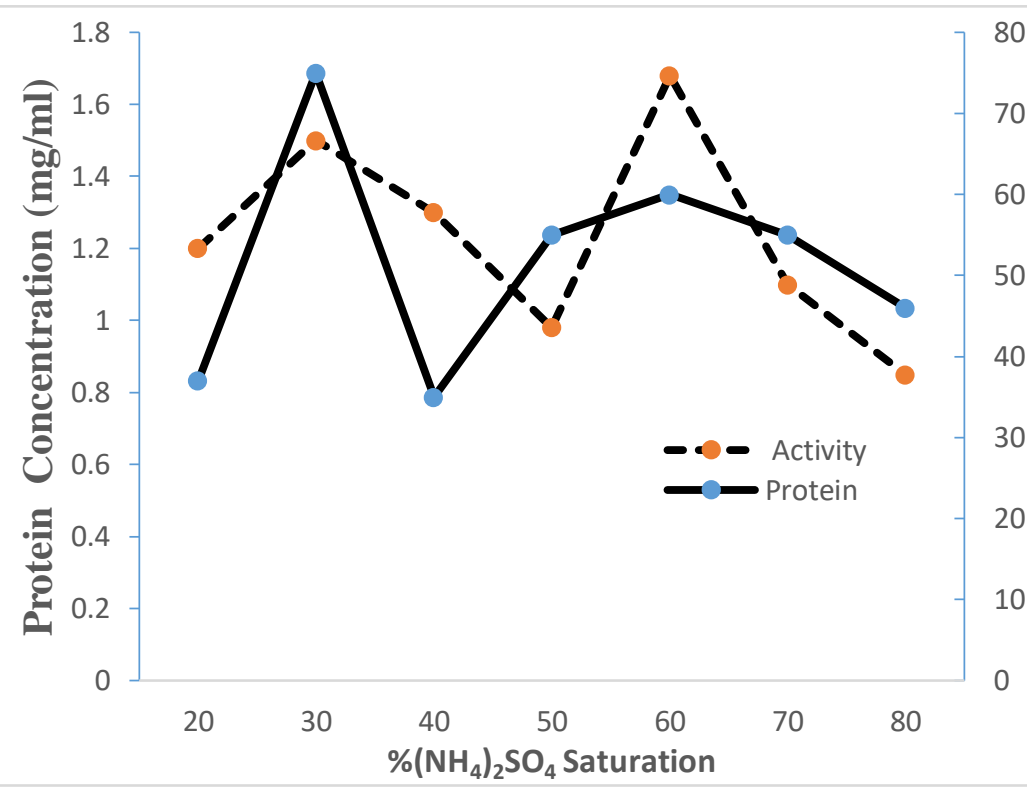

80

70

60

50

10

递

Figure 5. Ammonium sulphate Profile of Protease Inhibitor from Extracts of Moringa oleifera Seeds.

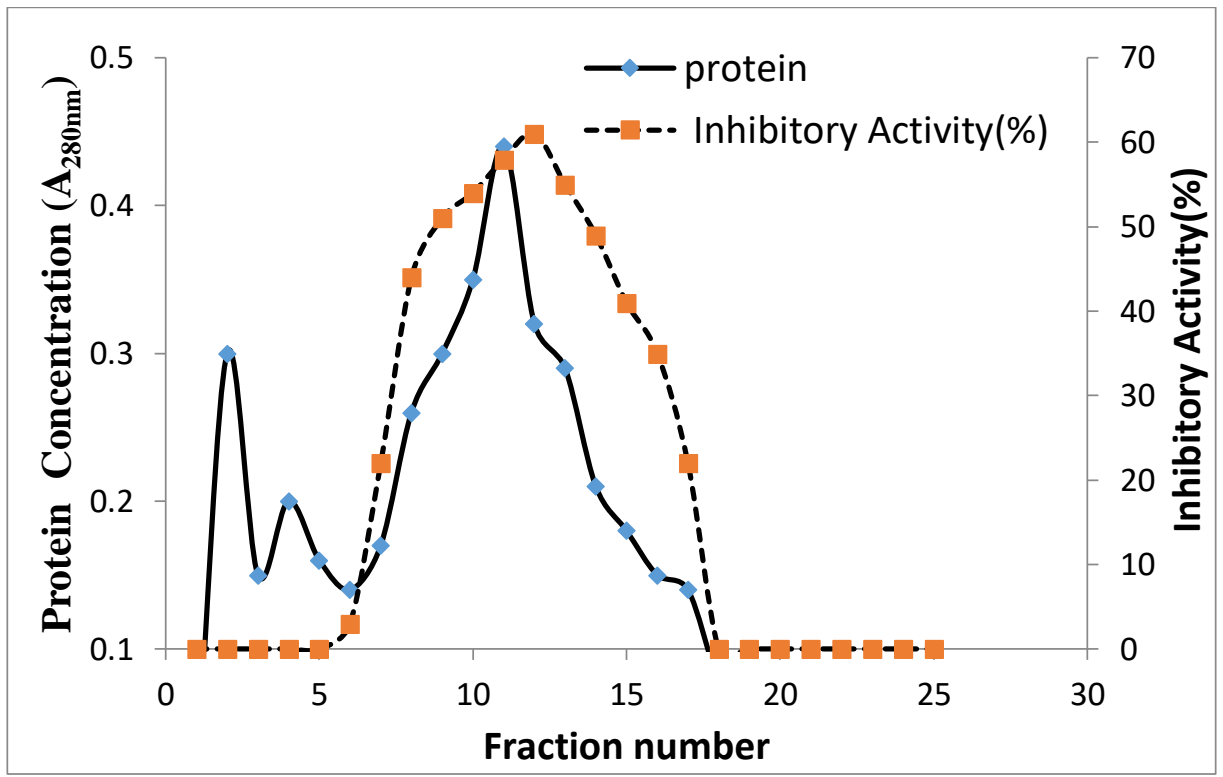

Figure 6: An Elution Profile for the Hydrophobic Interaction Chromatography of Moringa oleifera Seeds Inhibitor on Phenyl-Sepharose Column 


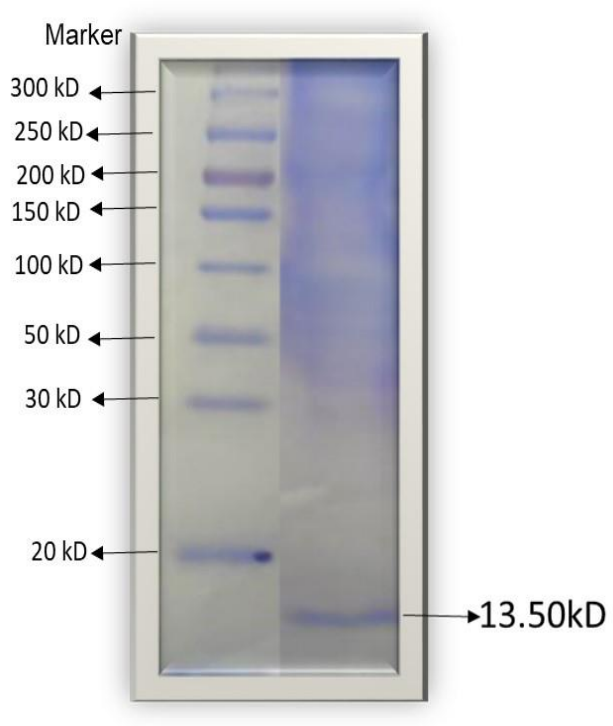

Figure 7: Electro-photograph of Partially Purified CPI from Moringa oleifera Seeds on SDS-PAGE.

\subsection{Discussion}

Several parasites causing diseases are dependent on cysteine proteases for their life-cycle. The central role of cysteine proteases in the pathogenesis and survival parasites in the host erythrocytes makes them attractive drug targets [2]. Inhibition of these proteases by natural proteins/peptides that will not have off target binding could be useful in the treatment of these parasitic diseases [1,2] Plants produce protease inhibitors to modulate the activity of self-proteases, but these molecules can also confer to them resistance to other exogenous proteases by pathogens and insect pest's attack. Consequently, taking advantages of plants that potentially inhibit this enzyme could be another source of antiparasitic agents.

In the present investigation, significantly higher specific cysteine protease inhibition was exhibited by phosphate buffer extract from the compared to other solvents, thus, phosphate buffer was selected as the effective extraction medium for maximal extraction of protease inhibitor without any loss in activity. This is because reports on solubilization of therapeutic proteins using various solvent system indicated that phosphate buffer extraction protect the protein structural integrity and conferred stability to these agents as these molecules are subjected to various forces aimed at isolating them for investigation [9]. Saline extract, which contain proteins from the latex of Moringa oleifera, was reported to have anticancer activities [16]. Other researchers used $0.01 \mathrm{~N} \mathrm{NaOH}$, distilled water [17] and $0.1 \mathrm{M}$ phosphate buffer, $\mathrm{pH} 7.5$ [9] as extraction media for various therapeutic proteins. Phosphate buffers at concentrations of 0.1-0.5 $\mathrm{M}$ are known for their solubilizing properties.

The crude phosphate buffer extracts from the seeds of Moringa oleifera was concentrated using cold acetone precipitation. The crude acetone protein precipitation exhibited dose dependent inhibitory activity with papain enzyme with an $\mathrm{IC}_{50}$ value of $1350 \mu \mathrm{g} / \mathrm{ml}$ Moringa oleifera. The maximum inhibitory activity was recorded at 50\% and $60 \%$ ammonium sulphate saturation. The ammonium sulphate solution is one of the commonest salt medium used in the initial steps in the protein purification. It has advantage over other solvents in stabilization of protein of interest. A 20-90\% ammonium sulphate saturation for Solanum aculeatissimum protease inhibitor was reported [17]. The low purification fold observed for Moringa oleifera seeds may be attributed to presence of activated protease enzyme or to some impurities interfering in this stage of purification, or it could also be due to stability factor.

Further purification of both inhibitors by Phenyl Sepharose chromatograph yielded several proteins fractions with a purification fold $42.3 \%$. PhenylSepharose as an adsorbent for hydrophobic interaction chromatography has been reported to be effective for the purification of some proteases, and with purification factors in the range of $2.9-60$ and activity yields more than $88 \%$ were obtained [13]. The increase in activity in this investigation is an indicative of exclusions of endogenous protease and an improved stability of the inhibitors.

SDS-PAGE analysis of the inhibitors under reducing conditions gave an estimated molecular weight of $13.35 \mathrm{kDa}$ (Figure 7). It was reported earlier that the molecular mass of CPI type inhibitors is in the range of $18-26 \mathrm{kDa}$ and are mostly monomeric or dimeric members. The two inhibitors isolated from this investigation fall outside the literature range for cysteine protease inhibitor. Other researcher had earlier reported small peptide and proteins of molecular weight between 5-15kDa, with cysteine protease inhibitory activity [18].

\subsection{Conclusion}

The seeds from the Moringa oleifera can be considered as an excellent source of isolating low molecular weight phytocystatin with in-vitro inhibitory activity against commercial cysteine protease. The isolated protein in this work could be useful in biotechnology of traditional medicinal plants, in transgenic crops to arrest the negative pathogenic over expressions of cysteine proteases. 
Further research on characterization of this molecule is ongoing.

Funding: This research did not receive any specific grant from funding agencies in the public, commercial, or not-for profit sectors.

Author's contributions: All authors contributed in preparing this article.

Conflict of interest: The authors declared no conflict of interest.

Acknowledgements: The authors appreciate the technical staff of the Department of Biochemistry, Ahmadu Bello University Zaria, Nigeria, for their kind assistance throughout the conduct of this study.

\section{References}

1. Karthik, L.; Kumar, G.; Keswani, T.; Bhattacharyya, A.; Chandar, S.S.; Bhaskara Rao, K. Protease inhibitors from marine actinobacteria as a potential source for antimalarial compound. PloS one 2014, 9, e90972.

2. Rosenthal, P.J. Cysteine proteases of malaria parasites. International journal for parasitology 2004, 34, 1489-1499.

3. Pirta, C.; Sharma, N.N.; Banyal, H. A 43 $\mathrm{kDa}$ recombinant plasmepsin elicits immune response in mice against Plasmodium berghei malaria. Acta parasitologica 2016, $61,102-107$.

4. Rosenthal, P.J.; Kim, K.; McKERROW, J.H.; Leech, J.H. Identification of three stagespecific proteinases of Plasmodium falciparum. The Journal of experimental medicine 1987, 166, 816-821.

5. Rao, N.M.; Rao, H.N.; Pattabiraman, T. Enzyme inhibitors from plants. Isolation and characterization of a protease inhibitor from arrow root (Maranta arundinaceae) tuber. Journal of Biosciences 1983, 5, 21-33.

6. Wen, R.; Zhang, S.C.; Michaud, D.; Sanfaçon, $\mathrm{H}$. Inhibitory effects of cystatins on proteolytic activities of the Plum pox potyvirus cysteine proteinases. Virus research 2004, 105, 175-182.

7. Adebayo, J.; Krettli, A. Potential antimalarials from Nigerian plants: a review. Journal of ethnopharmacology 2011, 133, 289-302.
8. Lawal, B.; Shittu, O.K.; Kabiru, A.Y.; Jigam, A.A.; Umar, M.B.; Berinyuy, E.B.; Alozieuwa, B.U. Potential antimalarials from African natural products: A reviw. Journal of intercultural ethnopharmacology 2015, 4, 318.

9. Bijina, B.; Chellappan, S.; Basheer, S.M.; Elyas, K.; Bahkali, A.H.; Chandrasekaran, M. Protease inhibitor from Moringa oleifera leaves: Isolation, purification, and characterization. Process Biochemistry 2011, 46, 2291-2300.

10. Wu, C.; Whitaker, J.R. Purification and partial characterization of four trypsin/chymotrypsin inhibitors from red kidney beans (Phaseolus vulgaris, var. Linden). Journal of Agricultural and Food Chemistry 1990, 38, 1523-1529.

11. Sritanyarat, W.; Pearce, G.; Siems, W.F.; Ryan, C.A.; Wititsuwannakul, R.; Wititsuwannakul, D. Isolation and characterization of isoinhibitors of the potato protease inhibitor I family from the latex of the rubber trees, Hevea brasiliensis. Phytochemistry 2006, 67, 1644-1650.

12. Bradford, M.M. A rapid and sensitive method for the quantitation of microgram quantities of protein utilizing the principle of protein-dye binding. Analytical biochemistry 1976, 72, 248-254.

13. Gupta, A.; Roy, I.; Patel, R.; Singh, S.; Khare, S.; Gupta, M. One-step purification and characterization of an alkaline protease from haloalkaliphilic Bacillus sp. Journal of chromatography A 2005, 1075, 103-108.

14. Laemmli, U.K. Cleavage of structural proteins during the assembly of the head of bacteriophage T4. nature 1970, 227, 680685.

15. Makut, M.D.; Madaiki, K.K.; Obiekezie, O.S. Molecular characterization of xanthan gum producing Xanthomonas Campestris isolated from dark rot spotted leaves in Keffi, Nasarawa State, Nigeria. AROC in Pharmaceutical and Biotechnology 2022, 2(1);01-08

16. Jung, S.-A.; Kim, K.-B.-W.-R.; Kim, M.-J.; Kim, D.-H.; SunWoo, C.; Kim, H.-J.; Jeong, D.-H.; Jeong, H.-Y.; Kim, T.-W.; Cho, Y.-J. Trypsin inhibitory activity of water extracts from Ecklonia cava as affected by temperature and $\mathrm{pH}$. Journal of the Korean 
Society of Food Science and Nutrition 2012, 41, 840-845.

17. Soares, A.; Carvalho, L.; Melo, E.; Costa, H.; Vasconcelos, I.; Oliveira, J. A protein extract and a cysteine protease inhibitor enriched fraction from Jatropha curcas seed cake have in vitro anti-Toxoplasma gondii activity. Experimental parasitology 2015, 153, 111-117.

18. De Oliveira, C.F.R.; Luz, L.A.; Paiva, P.M.G.; Coelho, L.C.B.B.; Marangoni, S.; Macedo, M.L.R. Evaluation of seed coagulant Moringa oleifera lectin (cMoL) as a bioinsecticidal tool with potential for the control of insects. Process Biochemistry 2011, 46, 498-504.

Copyright (c) 2022 Abdulkadir et al. This is an open access article distributed under the terms and conditions of the Creative Commons Attribution License (https://creativecommons.org/licenses/by/4.0/) 